\title{
A Message to the 2500th Buddha' Jayanti Celebration from the Japanese Association of Indian and Buddhist Studies
}

\section{Presented by the Director, Dr. Shoson Miyamoto}

Mr. Chairman, Venerable Theras, Delegates, Ladies and Gentlemen:

As director of the Japanese Association of Indian and Buddhist Studies and on behalf of its members, may I extend our sincere congratulations on this great occasion, the 2500th Buddha Jayanti Celebrations. Furthermore, we, Dr. Hajime Nakamura and I, wish to express our deep appreciation for being able to participate in the Celebrations as honored state guests of the Indian Government.

The people of Japan have very high respects and regards for your Government's unceasing and unflinching efforts in projecting and promoting a humanism in the midst of East-West opposition and tension. We sincerely believe that the Celebrations are not a mere coincidence of the times, but a humble reminder to the world of the enormous Buddhist influence and contribution in all walks of life.

Buddhism has always respected human freedom above everything else and has promoted the general welfare and happiness of the people wherever it spread. And it seems that, today, its spirit of tolerance and candid view of truth have created a common ground of discourse and action for a harmonious livelihood of all the races of the world. Moreover, it will in the future play an increasingly important role in harmonizing man's scientific power of discovery and the forces of Universal Mother Nature, thereby guide and direct in establishing a life of harmony and happiness for a11.

Perhaps, it is not saying too much that our presence here has virtually bridged the gaps or differences existing among the Asian countries. But 
we are equally sure that the Indian Government envisages the influence of Indian cultures not only peculiarly Asiatic, but also on the wider and loftier scale of internationalism and universalism. In Japan, the Association of Indian and Buddhist Studies is actively carrying out meritorious work and service in its field, and all its members constantly maintain great interest in your country, your people, and your esteemed culture. We have come not as individuals but as individuals representing all the Buddhist scholars and the people of Japan, bringing their good wishes to you.

The 2500th Buddha Jayanti Celebrations will long remain in our memories.....especially for us who have come from the farthest arm of the Asiatic continent, Japan. It has brought to our hearts the very essence of Buddhism in its true historical setting and reminded us why it has remained to posterity as a great religious force. We would like to bring back to the people of Japan the rare and wonderful things we have seen and experienced. I am sure they will all appreciate this very much.

$$
\times \times \times \times
$$

昭和三十一年十一月廿四日より一週間ニューデリーに開催されたインド政府主催佛隇二千五 百年記念式典並にエネスコ佛敉シンポジュームに（次の二週間はサンチー，クシナーガラ，サ ルナート，ブッダガヤ，ラーヂャギリ，ナーランダ，カルカッタにおける式典に）ネール首相 の招待により，宮本中村兩博士が出席されました。

The Japanese Association of Indian and Buddhist Studies, through its director, Dr. S. Miyamoto, respectively and individually presented the following volumes to His Excellency, the Honorable Jawaharla1 Nehru, Prime Minister of India, and His Excellency, the Honorable Sarvepalli Radhakrishnan, Vice President of India.

I . Japanese Sculpture, a six-volume pictorial collection.

II. Special Supplementary Issue of the Journal of Indian and Buddhis: Studies, April 1955.

III. The Fundamental'Truth of Buddhism or Bukkyo no Konpon Shinri (November 1956), an up-to-date specialized studies in Buddhism by Japanese scholars. 